\title{
The Effects of Water Consumption on the Eating and Rumination Behaviour of Sheep Fed Only Fresh or Dried Forage
}

\author{
Tsutomu FujIhara, Masayo Sumida and Tadashi Harumoto \\ Faculty of Agriculture, Shimane University, Matsue-shi 690
}

(Received September 1, 1988)

\begin{abstract}
This experiment was carried out in order to investigate the effects of equalized or restricted water consumption on eating and rumination behaviour in sheep receiving only fresh or dried-grass in similar amounts. Daily time spent eating the dried grass tended to be fairly prolonged when water consumption was forcedly equalized to that for fresh-grass feeding, while the time spent markedly decreased due to restricted water intake after feeding dried-grass. The lag time after eating dried-grass tended to decrease due to the equalization of water consumption, and to increase somewhat via the restriction of water intake. The daily time spent ruminating did not change in the case of either feeding dried-grass with equalization or restriction of water consumption. The difference in water consumption did not affect the rumination index (time spent ruminating/ $100 \mathrm{~g}$ D.M. eaten) and the rumination efficiency in sheep given access to forage diets with similar amounts of dry matter.
\end{abstract}

Jpn. J. Zootech. Sci., 60 (4): 387-395, 1989

Key words : sheep, water consumption, eating behaviour, rumination

It is clear in ruminants that the act of chewing during eating and ruminating has an important role in the reduction of particle size of ingested food ${ }^{13}$, and that rumination behaviour is considered to be an important function related to the utilization of roughage feed ${ }^{2-5)}$. It is also well known that the physical form of feed considerably affects eating and rumination behaviour, and that eating and rumination behaviour is considerably influenced by changes in dietary chemical composition ${ }^{6-9)}$.

There have been several investigations on eating and rumination behaviour in relation to the digestion of roughage in either the fresh or dried form, using sheep ${ }^{10-12)}$. It has been suggested that the rumination of sheep is more intensive and efficient in the case of fresh-grass feeding than in hay feeding ${ }^{11)}$. The difference in physical form property of fresh-grass and hay (or dried grass) harvested at the same growing stage from the same pasture might be due mainly to the difference in moisture content of the ration. In the present study, the eating and rumination behaviour of sheep fed only fresh or dried-grass in similar amounts, when the water consumption was equalized or restricted in dried-grass feeding, were investigated in detail. 


\section{Materials and Methods}

\section{Animals and diets}

Three Japanese Corriedale male sheep (nos. 531, 541 and $k$ 790) and one wether (no. F 535), each weighing $32-42 \mathrm{~kg}$, were used repeatedly. These sheep were allocated for the two Experiments as follows ; Experiment I, 531, 541 and F 535 ; Experiment II, 531,541 and $\mathrm{k} 790$, respectively.

The fresh-grass was harvested each morning from a predominantly Italian ryegrass pasture at heading stage (Expt. I) or before heading stage (Expt. II). The dried-grass was made from the herbage harvested at the same time as the fresh-grass, using a forced-air oven $\left(55^{\circ} \mathrm{C} / 24 \mathrm{hr}\right.$.). Each grass diet was cut about $5-8 \mathrm{~cm}$ long before feeding. Chemical composition (as \% of D.M.) of the fresh and dried-grass, determined by the method of $\mathrm{AOAC}^{13)}$, is shown in Table 1 .

\section{Experimental procedure}

Experiment I: The experimental animals were kept in metabolism cages throughout the experimental period. Each animal was fed the fresh-grass diet for 12 days (1st period) and thereafter they were fed the dried-grass diet for 12 days (2nd period) in the two trials using 1 st and 2nd cut forages. Five-day sampling periods were preceded by 7 -day preliminary periods. Each sheep was fed about $2.0 \%$ as dry matter of diet per $\mathrm{kg}$ of body weight per day. Fresh water was freely available at all time in fresh-grass feeding, and in dried-grass feeding, water intake was equalized to that in fresh-grass feeding. To equalize the water intake, in dried-grass feeding, the sheep were forcibly given some volume of water (calculated volume and what's left after free drinking) through a stomach tube just after eating dried-grass.

Experiment II : Water intake in dried-grass feeding was restricted to about $50 \%$ of that in fresh-grass feeding, and the other procedures were similar to that of Experiment I mentioned above.

The lag time (rumination appearance) was defined as the interval between the end of the main meal and the first rumination activity. The other experimental procedures were as described previously ${ }^{11)}$, and the statistical analysis of the data was determined

Table 1. Chemical composition of diet

\begin{tabular}{|c|c|c|c|c|c|c|c|c|}
\hline \multirow[t]{2}{*}{ Expt } & \multicolumn{2}{|c|}{ Diet } & \multirow{2}{*}{$\begin{array}{l}\text { Mois - } \\
\text { ture }\end{array}$} & \multirow{2}{*}{$\begin{array}{l}\text { Organic } \\
\text { matter }\end{array}$} & \multirow{2}{*}{$\begin{array}{l}\text { Crude } \\
\text { Protein }\end{array}$} & \multirow{2}{*}{$\begin{array}{l}\text { Crude } \\
\text { fat }\end{array}$} & \multirow{2}{*}{$\begin{array}{l}\text { Crude } \\
\text { fibre }\end{array}$} & \multirow[b]{2}{*}{$\mathrm{NFE}$} \\
\hline & Cutting & Form & & & & & & \\
\hline \multirow[t]{4}{*}{ I } & 1 st cut & Fresh & $78.1^{* *}$ & $91.3^{* * *}$ & 11.4 & 2. 5 & 28.0 & 49.4 \\
\hline & & Dried & 12.2 & 91.7 & 10.5 & 2.6 & 31.1 & 47.5 \\
\hline & 2 nd cut & Fresh & 80.6 & 91.3 & 10.7 & 3. 1 & 31.8 & 45.7 \\
\hline & & Dried & 12.2 & 91.3 & 10.7 & 3.0 & 34.4 & 43.2 \\
\hline \multirow[t]{2}{*}{ II } & 1 st cut \# & Fresh & 84.5 & 93.1 & 14.6 & 3. 2 & 19. 1 & 56.2 \\
\hline & & Dried & 15.0 & 92.4 & 12. 1 & 3.0 & 19.8 & 57.5 \\
\hline
\end{tabular}

* Nitrogen free extracts. ** \% of fresh matter. **** 96 of dry matter.

\# Early cut (before heading out). 
by the $t$-test ${ }^{14}$.

\section{Results}

As shown in Table 1, the crude protein content of the 1st cut forage used in Experiment I was slightly lower in the dried form than in the fresh form, and inversely the crude fibre content was slightly higher in the former than in the latter. Chemical composition of the 2nd cut forage was very similar in fresh or dried form. In Experiment II, the crude protein content in the dried-grass was slightly lower than that in the fresh-grass. The crude protein content of the diets used in Experiment II was slightly higher than that of diets used in Experiment I, and the crude fibre content of the diets in Experiment II was extremely lower than that of the diets in Experiment I.

Experiment I. The eating and ruminating behaviour of sheep fed only fresh or dried-grass with equalized water consumption

The daily time spent eating fresh-grass was almost similar to that of eating dried-grass when sheep were fed on the 1st cut forage (Table 2). The rate of eating ( $g$ D.M./min) fresh-grass was also similar to that of eating dried-grass. Rumination appearance (lag time after eating) tended to grow shorter after feeding dried-grass with equalized water intake compared to after feeding fresh-grass. The daily time spent eating dried-grass was extremely longer, but not significantly, than that of eating fresh-grass when sheep were fed on the 2 nd cut forage. The rate of eating was almost similar in both feedings of fresh and dried-grass. Rumination appearance was significantly shorter in dried-grass feeding than in fresh-grass feeding.

The daily time spent ruminating and the number of boli regurgitated were similar in both feedings of fresh and dried-grass in sheep fed on the 1st cut forage. The cyclic

Table 2. Eating behaviour and the lag time after eating in sheep fed only fresh or dried grass with equalized (Expt. I) or restricted (Expt. II) water intake

\begin{tabular}{|c|c|c|c|c|c|c|}
\hline \multirow{3}{*}{ Diet } & \multicolumn{4}{|c|}{ Experiment I } & \multirow{2}{*}{\multicolumn{2}{|c|}{$\frac{\text { Experiment II }}{1 \text { st cut } \#}$}} \\
\hline & \multicolumn{2}{|c|}{$1 \mathrm{st} \mathrm{cut}$} & \multicolumn{2}{|c|}{2 nd cut } & & \\
\hline & Fresh & Dried & Fresh & Dried & Fresh & Dried \\
\hline $\begin{array}{l}\text { Time spent } \\
\text { eating }(\min )\end{array}$ & $\begin{array}{l}105.6 \pm 7.1^{*} \\
(855.8)^{* *}\end{array}$ & $\begin{array}{c}103.7 \pm 6.7 \\
(901.3)\end{array}$ & $\begin{array}{r}118.2 \pm 7.2 \\
(709.2)\end{array}$ & $\begin{array}{c}150.8 \pm 18.5 \\
(889.7)\end{array}$ & $\begin{array}{c}115.3 \pm 5.5^{\mathrm{a}} \\
(703.3)\end{array}$ & $\begin{array}{c}66.815 .8^{b} \\
(714.8)\end{array}$ \\
\hline $\begin{array}{l}\text { Rate of eating } \\
\text { (g D.M. / min) }\end{array}$ & $\begin{array}{c}8.2 \pm 0.6 \\
(198.5) \sharp\end{array}$ & $\begin{array}{c}8.7 \pm 0.3 \\
(191.3)\end{array}$ & $\begin{array}{l}6.0 \pm 0.2 \\
(200.4)\end{array}$ & $\begin{array}{l}5.9 \pm 0.5 \\
(190.9)\end{array}$ & $\begin{array}{l}6.1 \pm 0.5^{\mathrm{a}} \\
(256.9)\end{array}$ & $\begin{array}{c}10.7 \pm 1.9^{b} \\
(141.1)\end{array}$ \\
\hline $\begin{array}{l}\text { Rumination } \\
\text { appearance }(\min )^{* * *}\end{array}$ & $132.3 \pm 8.0$ & $111.9 \pm 30.8$ & $146.6 \pm 4.5^{a}$ & $104.0 \pm 11.1^{b}$ & $249.1 \pm 81.7$ & $306.1 \pm 106.5$ \\
\hline
\end{tabular}

* Mean \pm S. E. of 3 sheep. ** Dry matter intake (g/day): mean of 3 sheep. *** Time after eating.

\# Early cut(before heading out). \#\#Water intake (g/kg B. $W^{0.75} /$ day $)$ ): mean of 3 sheep.

$a-b:$ Significance of difference between means of fresh and dried $(P<0.05)$. 
rate $^{1)}$ was almost the same in both feeding treatments, as the total rumination time (in second) per number of boli regurgitated. The daily number of rumination periods tended to increase slightly after feeding dried-grass. Therefore, both the length of rumination period and the number of boli per rumination period slightly decreased with the feeding of dried-grass. On the 2nd cut forage, the daily time spent ruminating was very similar in both feeding treatments. The daily number of boli regurgitated was fairly small after feeding dried-grass as compared with that after feeding fresh-grass, and therefore, the cyclic rate was somewhat greater when feeding on dried-grass than when feeding on fresh-grass. The number of rumination periods per day was slightly more after feeding dried-grass campared to after feeding fresh-grass. The length of rumination period and the number of boli per rumination period were also slightly greater in fresh-grass feeding than in dried-grass feeding.

The rumination index ${ }^{11)}$ (time spent ruminating/100 g D.M. eaten) was almost similar in both feedings of fresh and dried-grass which consisted of the 1st cut forage. There was a slight increase in the number of chews per bolus and bolus time in dried-grass feeding, and the rumination chewing rate per minute in feeding fresh-grass or dried-grass was almost similar. The rumination index with the 2 nd cut forage was significantly small in feeding dried-grass than in feeding fresh-grass, although the dry matter intake was not always the same in both feedings. The number of chews per bolus and the bolus time were slightly higher in dried-grass feeding than in fresh-grass feeding, and chewing rate during rumination was almost the same in both feeding treatments.

Experiment II. The eating and ruminating behaviour of sheep fed only fresh or dried-grass with restricted water intake

The daily time spent eating dried-grass was significantly shorter than eating fresh-grass, and therefore, the rate of eating was also higher in feeding dried-grass than in feeding fresh-grass. Rumination appearance tended to be longer in feeding dried-grass than in feeding fresh-grass, though there were some differences among individual sheep.

The daily time spent ruminating was similar in both feedings, and the daily number of boli regurgitated tended to decrease in feeding dried-grass with a decreased water intake (Table 3). The daily number of rumination period slightly increased after feeding dried-grass, and the cyclic rate for fresh-grass was slightly shorter than that for dried-grass. The length of rumination period and the number of boli per rumination period tended to decrease slightly after feeding dried-grass with a decrease of water intake.

The rumination index was similar in both feeding treatments (Table 4). The number of chews per bolus and the bolus time were similar in both feeding treatments. The rumination chewing rate tended to slow after feeding dried-grass as compared to that after feeding fresh-grass. 
Eating and Rumination Behaviour in Sheep

Table 3. Rumination behaviour in sheep fed only fresh or dried grass with equalized (Expt. I) or restricted (Expt. I) water intake

\begin{tabular}{|c|c|c|c|c|c|c|}
\hline \multirow{3}{*}{ Diet } & \multicolumn{4}{|c|}{ Experiment I } & \multirow{2}{*}{\multicolumn{2}{|c|}{$\frac{\text { Experiment II }}{1 \text { st cut }}$}} \\
\hline & \multicolumn{2}{|c|}{1 st cut } & \multicolumn{2}{|c|}{2 nd cut } & & \\
\hline & Fresh & Dried & Fresh & Dried & Fresh & Dried \\
\hline $\begin{array}{l}\text { Ruminating time } \\
(\mathrm{min} / \text { day })\end{array}$ & $533.5 \pm 18.1^{*}$ & $538.8 \pm 35.5$ & $573.5 \pm 14.5$ & $569.8 \pm 33.3$ & $449.7 \pm 9.5$ & $458.3 \pm 30.3$ \\
\hline $\begin{array}{l}\text { No. of boli } \\
\text { regurgitated/day }\end{array}$ & $532.1 \pm 16.7$ & $521.5 \pm 15.2$ & $581.3 \pm 27.7$ & $528.8 \pm 19.6$ & $537.3 \pm 73.7$ & $492.0 \pm 24.6$ \\
\hline $\begin{array}{l}\text { No. of rumination } \\
\text { period/day }\end{array}$ & $19.7 \pm 1.9$ & $23.1 \pm 4.6$ & $21.4 \pm 4.4$ & $25.6 \pm 5.7$ & $15.3 \pm 4.5$ & $21.0 \pm 8.5$ \\
\hline Cyclic rate $(\mathrm{sec})^{* *}$ & $60.4 \pm 3.3$ & $62.2 \pm 3.8$ & $59.6 \pm 3.9$ & $64.6 \pm 3.3$ & $50.3 \pm 6.1$ & $56.0 \pm 4.5$ \\
\hline $\begin{array}{l}\text { Length of rumination } \\
\text { period }(\min )\end{array}$ & $30.1 \pm 3.4$ & $25.9 \pm 6.1$ & $30.8 \pm 8.1$ & $26.3 \pm 8.8$ & $31.1 \pm 9.1$ & $25.5 \pm 13.8$ \\
\hline $\begin{array}{l}\text { No. of boli per } \\
\text { rumination period }\end{array}$ & $28.6 \pm 3.6$ & $24.6 \pm 6.1$ & $30.8 \pm 7.6$ & $24.1 \pm 7.6$ & $36.2 \pm 6.1$ & $26.7 \pm 12.7$ \\
\hline
\end{tabular}

* Mean \pm S.E. of 3 sheep. ** Total rumination time (sec) no. of boli regurgitated.

\# Early cut (before heading out).

Table 4. Rumination efficiency in sheep fed only fresh or dried grass with equalized (Expt. I) or restricted (Expt. II ) water intake

\begin{tabular}{|c|c|c|c|c|c|c|}
\hline \multirow{3}{*}{ Diet } & \multicolumn{4}{|c|}{ Experiment I } & \multirow{2}{*}{\multicolumn{2}{|c|}{$\frac{\text { Experiment II }}{1 \text { st cut } \#}$}} \\
\hline & \multicolumn{2}{|c|}{1 st cut } & \multicolumn{2}{|c|}{2 nd cut } & & \\
\hline & Fresh & Dried & Fresh & Dried & Fresh & Dried \\
\hline Rumination index $*$ & $62.3 \pm 1.5^{* *}$ & $59.8 \pm 3.6$ & $81.4 \pm 1.3$ & $65.5 \pm 3.6$ & $64.2 \pm 7.8$ & $64.9 \pm 7.8$ \\
\hline $\begin{array}{l}\text { No. of chews } \\
\text { per bolus }\end{array}$ & $51.5 \pm 8.1$ & $57.1 \pm 7.4$ & $57.6 \pm 9.1$ & $64.7 \pm 8.7$ & $54.0 \pm 7.9$ & $50.7 \pm 3.0$ \\
\hline Bolus time ( $\mathrm{sec}$ ) & $40.1 \pm 4.2$ & $45.7 \pm 3.9$ & 44. $5 \pm 4.1$ & $50.5 \pm 4.2$ & 41. $0 \pm 7.2$ & $40.3 \pm 1.6$ \\
\hline $\begin{array}{l}\text { Rumination chewing } \\
\text { rate/min }\end{array}$ & $76.4 \pm 4.1$ & $24.6 \pm 1.7$ & $75.5 \pm 4.4$ & $76.0 \pm 5.1$ & $79.4 \pm 8.0$ & $72.8 \pm 6.3$ \\
\hline
\end{tabular}

* Time spent ruminating $/ 100 \mathrm{~g}$ D.M. eaten. ** Mean \pm S. E. of 3 sheep.

\# Early cut (before heading out).

\section{Discussion}

As shown in Table 1, the chemical composition of grass diet was very similar to that indicated in a standard table on Italian ryegrass at each cutting stage ${ }^{15)}$. The differences in the contents of crude protein and crude fibre in the diets used in Experiments I and II may be due to the difference in the growing stages of the herbages because the forages were harvested at heading stage in Experiment I (1st and 2nd cutting), and was at an early stage (before heading) in Experiment II.

In Experiment I, the daily time spent eating dried-grass fairly increased as compared with that for fresh-grass when sheep were fed on the 2nd cut forage, and the 
rate of eating did not change in both feeding treatments. This would be due to a slight increase of feed intake of dried-grass. In Experiment II, the daily time spent eating dried-grass was significantly shorter than that of eating fresh-grass, and therefore, the sheep ate the dried-grass significantly faster than the fresh-grass. This result is consistent with those reported previously ${ }^{11)}$ and by other researchers ${ }^{10,12}$. OsuJI et al. ${ }^{103}$ reported that the rate of eating was significantly slower in fresh-grass feeding than in dried-grass feeding when sheep were given access to similar amounts of dry matter. FUJIHARA ${ }^{11)}$ also reported that the time spent eating fresh-grass was rather longer than for hay, and the sheep ate the hay faster when they were fed only fresh-grass or hay in equal amounts. These facts were obviously confirmed by the result of the present study (Expt. II), in which the water intake of sheep was restricted in feeding dried-grass. In general, it would be presumed that the difference of bulk in the daily ration influences the acceptability and rate of eating feed by ruminants. It can also be considered that fresh-grass would be more difficult to make into a bolus for swallowing than hay. Therefore, FuJIHARA ${ }^{11)}$ had previously suggested that the difference of ease of bolus making might induce a difference in eating time between fresh-grass and hay feeding. He also reported that the difference in time spent eating was mainly due to a difference in physical pliability and/or particle size of dietary fibre when sheep were fed only dried fibrous-residue of oat or Italian ryegrass ${ }^{16)}$. In the present study, the result obtained in Experiment II, in which the water intake by sheep was restricted in dried-grass feeding, obviously emphasizes the fact described earlier $^{11}$. In Experiment I, however, the time spent eating dried-grass was almost similar to or rather longer than that for fresh-grass, and the rate of eating was not fast in dried-grass feeding. This might show that the equalized water intake after feeding dried-grass clearly affected the eating behaviour of sheep given access to similar amounts of dry matter from fresh or dried-grass. It also suggests that there might be other factors other than those mentioned above which affects the eating behaviour of sheep ${ }^{11,16)}$. Therefore, it is necessary to consider if other factors might also influence the response of the rumen volume and/or the composition of ruminal ingesta to time spent eating food in ruminants. In the present study (Expt. I) the sheep were forcibly given some volume of water through a stomach tube just after eating dried-grass in order to equalize water consumption to that after eating fresh-grass. There might be stress by forcibly giving water to sheep eating feed. From the results of this study, it was verified that the difference in time spent eating fresh-grass and hay (or dried-grass) as described earlier ${ }^{11)}$ could be mainly due to a difference of water intake in both feeding treatments. Furthermore, it can be easily presumed that the ruminal dose of water should give some "physiological load" to the sheep receiving dried-grass, i.e., the energy cost to sheep would be increased in feeding dried-grass as reported previously ${ }^{11}$. There is also another evidence that the time spent eating low-quality roughage clearly decreased by the use of an oral or intraruminal supplementation of nitrogenous compounds ${ }^{6.9}$. Therefore, it may be considered in this study that some changes in the chemical or physical property of 
ruminal ingesta affect the eating behaviour of sheep receiving dried-grass when they were forcibly given some water just after feeding.

The daily lag time (between eating and ruminating) in Experiment I tended to be long after feeding fresh-grass as compared with that after feeding dried-grass, particularly, with the 2nd cut forage the difference in feeding fresh-grass and dried-grass was statistically significant. This clearly shows the effects of water consumption on certain stimuli of ruminal volume to a receptor of rumen wall for raising rumination, because an initiation of ruminating would be more late after hay feeding than after fresh-grass feeding when sheep were fed similar amounts of dry matter ${ }^{11)}$. The rumination appearance (lag time) was fairly late with dried-grass and restricted water consumption in Experiment II, although there were some variations in figures among individual sheep. This would emphasize the fact obtained in the previous study described above ${ }^{(1)}$.

In comparison with the rumination behaviour in sheep receiving fresh-grass or dried-grass, Osusi et al. ${ }^{10)}$ previously reported that the sheep spent more than twice as long ruminating after a single meal when given fresh-grass than when given dried-grass. FuJIHARA ${ }^{11)}$ also reported that daily time spent ruminating was fairly longer in fresh-grass feeding than in hay feeding when sheep were fed similar amounts of dry matter. In the present study, however, the daily time spent ruminating and the number of boli regurgitated did not change in both feedings of fresh-grass and dried-grass (Expt. I). Therefore, the cyclic rate was also similar in all the dietary treatments. These facts show clearly that the rumination activity in sheep was fairly stimulated by an increase in water intake in feeding dried-grass. When water consumption was restricted in feeding dried-grass (Expt. II), the daily time spent ruminating and the number of boli regurgitated were similar in both feeding treatments, and therefore, the cyclic rates in both feedings were also similar. These findings did not support the results reported earlier ${ }^{11)}$, in which the sheep were fed only forage diets in either the fresh or dried form without any treatments of water consumption. The water intake of sheep receiving hay was about $70-75 \%$ of that consumed in fresh-grass feeding when they were given access to similar amounts of dry matter ${ }^{11)}$.

OsuJI et al. ${ }^{101}$ reported that, in sheep after a single meal, the rumination index was more than twice as great in fresh-grass feeding as in dried-grass feeding, though the dry-matter intake was slightly different between fresh-grass feeding (595 g D.M.) and dried-grass feeding (541 g D.M.). FUJIHARA ${ }^{11)}$ also described previously that the rumination index was slightly high with fresh-grass than with hay in sheep given access to similar amounts of dry matter. In this study, dry-matter intake of sheep was almost the same in the two Experiments with the exception of the dry-matter intake which was quite small in feeding fresh-grass of the 2nd cut forage (Expt. I). The rumination index with fresh grass was significantly greater than that with dried-grass after feeding with the 2nd cut forage (Expt. I). This difference would be mainly due to the difference of dry-matter intake in both feeding treatments, because 
it is obvious that the time spent ruminating per $\mathrm{kg}$ dry matter ingested tends to increase with a decrease of dry-matter intake ${ }^{17,18)}$. The rumination index did not change in Experiment II, in which the water consumption in dried-grass feeding was restricted to about a half of that in fresh-grass feeding. There was also no large difference in the rumination index between the two Experiments, although the quality of forage was quite different in both feeding treatments. From the above, it can be presumed that the rumination index would not be affected with a change of water consumption in sheep receiving similar amounts of dry matter in roughage feed.

In order to investigate an efficiency of rumination for comminuting the feed eaten, the number of chews per bolus, bolus time and the chewing rate of rumination were measured. The number of chews per bolus and the bolus time slightly tended to increase in dried-grass feeding when the water consumption was equalized to that in fresh-grass feeding (Expt. I), and this was obviously opposed to what has been reported previously ${ }^{11}$, in which the sheep were fed only fresh-grass or hay with an unlimited amount of water. Subsequently, the chewing rate during rumination was almost similar in both feedings of fresh-grass and dried-grass, and this is also the opposite result of what was described earlier ${ }^{11)}$. These findings would clearly suggest that chewing during rumination after feeding dried-grass might be confused by an increase in water consumption. On the other hand, the rumination efficiency in Experiment II nearly confirmed the results obtained in the earlier study ${ }^{11}$, in which the chewing rate was higher in fresh-grass feeding than in hay feeding, that is, the rumination of sheep was more intensive in the former than in the latter.

\section{Acknowledgement}

We are grateful to Mr. T. Kasuga for his helpful assistance during the experiment.

\section{References}

1) Gordon, J.G., pH D. thesis (University of Aberdeen), 1955.

2) BALCH, C.C., Br. J. Nutr., 26 : 383-392. 1971.

3) Ørskov, E.R., C. Fraser and J.G. Gordon, Br. J. Nutr., 32 : 59-69. 1974.

4) Fujhinara, T., J. Agr. Sci. Camb., $97:$ 485-488. 1981.

5) Sudweeks, E.M., M.E. Mcgullough, L.R. Sike and S.E. Law, J. Anim. Sci., 41 : 219 224. 1975.

6) Campling, R.C., M. Fraser and C.C. Balch, Br. J. Nutr., $16: 115-124.1962$.

7) Welch, J.G. and A.M. Smith, J. Anim. Sci., 28: 813-818. 1969.

8) Fujihara, T. and T. Nakao, J. Agr. Sci. Camb., $98: 237-240.1982$.

9) Fujihara, T. and T. NaKaO, Jpn. J. Zootech. Sci., 55 : 199-203. 1984.

10) Osuji, P.O., J.G. Gordon and A.J.F. Webster, Br. J. Nutr., 34: 59-71. 1975.

11) Fujihara, T., J. Agr. Sci. Camb., 95: 729-732. 1980.

12) Harumoto, T. and M. Kato, Bull. Fac. Agr. Shimane Univ., 12: 20-25. 1978. (in Japanese).

13) Hoitz, H. (ed.), Official Methods of Analysis, 9th ed. AOAC. Washington, D.C., 283-288. 1960.

14) Yoshida, M., Design of Experimental for Animal Husbandry. 69-73. Yokendo Co. 


\section{Eating and Rumination Behaviour in Sheep}

Tokyo. 1975. (in Japanese).

15) National Research Council of Agriculture, Forestry and Fisheries, Standard Tables of Feed Composition in Japan. 38-39. 1980.

16) Fujtrara, T., Jpn. J. Zootech. Sci., 58: 538-542. 1987.

17) Freer, M. and R.C. CAMpling, Br. J. Nutr., 19: 195-207. 1965.

18) Hancock, J., Anim. Breed. Abstr., 21 : 13-23. 1953.

\section{生草又は乾草を摂取しているヒッジの採食, 反瑤行動 に対する飲水量の影響について \\ 藤原 勉 - 隅田真代 - 春本 直 \\ 島根大学農学部，松江市 690}

同一固場から刚り取った牧草を，生草で給与した場合 と乾草 (人工乾燥) として給与した場合のヒッジにおけ る採食, 反蜀行動について比較し，特に乾草給与時の水 分摄取量を生草給与時と等しくした場合と約 $50 \%$ に制 限した場合の採食，反㙁行動に及ぼす影響について検討 した． 1 日当たり乾草の採食時間は，水分摄取量を等し くした場合には長くなる傾向が認められ，一方飲水制限 すると著しく短縮された，乾草の採食後，反鴽発現まで
の時間（ラグタイム）は飲水量を等しくした場合は短 くなり，飲水制限すると長くなる㑯向が見られた．1日 当たりの反虽時間は水分摄取量の変化による明らかな影 響は受けないようであった，摄取乾物 $100 \mathrm{~g}$ 当たりの 反絢時間および反緆効率にも水分攝取量の差による明ら かな变化はみられなかった。

日畜会報，60(4)：387-395，1989 